\title{
Premenopozal ve postmenopozal kadınlarda lipit profili ve plazma aterojenik indeksinin karşılaştırılması
}

\section{Comparison of serum lipid profile and plasma atherogenic index between premenopausal and postmenopausal women}

\section{Cennet Yıldız ${ }^{1}$, Abdülmelik Yıldız ${ }^{2}$, Fatih Tekiner ${ }^{2}$}

\section{ÖZET}

Amaç: Menopoz ile birlikte hormonal durum, metabolizma ve lipit profilinde bir takım değişiklikler meydana gelir. Çalışmamızın amacı yaşın ve menopozun lipit profilinde meydana getirdiği değişiklikleri incelemektir.

Yöntemler: Çalışmaya sağlıklı 160 postmenopozal ve 260 premenopozal kadın alındı. Tüm olgulara bir anket formu doldurtuldu. Tüm olguların total kolesterol (TK), yüksek yoğunluklu lipoprotein kolesterol (HDL-K), düşük yoğunluklu lipoprotein kolesterol (LDL-K), trigliserid (TG) ve plazma aterojenik indeksi (PAI) değerlendirildi. Premenopozal kadınlar ayrıca 22-45 yaş ile ve 45 yaş üzeri olmak üzere iki gruba ayrıldı.

Bulgular: Menopoz sonrası kadınlarda TK, LDL-K, TG ve PAI değerleri anlamlı olarak yüksek bulunurken, HDL-K seviyesinde anlamlı fark saptanmadı. Kırk beş yaş üzeri premenopozal kadınlarda sadece LDL-K seviyesi anlamlı olarak yüksek bulundu.

Sonuç: Menopoz lipit profilinde değişiklikler ile birliktedir. Plazma aterojenitesi için bir belirleyici olan PAI, postmenopozal kadınlarda ateroskleroz riski için kullanılabilir.

Anahtar kelimeler: Menopoz, lipit profili, plazma aterojenik indeksi.

\section{GíRiș}

Menopoz ovaryan aktivitenin kaybına bağlı olarak menstürasyonun kalıcı şekilde sonlanması ve östrojen üretiminin azalması olarak tanımlanır. Menopoz sırasında ve sonrasında östrojen düzeyinin düşmesi

\begin{abstract}
Objective: Menopause leads to changes in hormonal status, metabolism and lipid profile. The aim of the present study was to determine the influence of menopause and age on lipid profile in women.
\end{abstract}

Methods: This study included 160 postmenopausal and 260 premenopausal healthy women. Serum lipid profile including total cholesterol (TC), high density lipoprotein cholesterol (HDL-C), low-density lipoprotein cholesterol (LDL-C), triglyceride (TG) and atherogenic index of plasma (AIP) were estimated. Premenopausal women were further arranged in to two different age group of 22-45 years and above 45 years of age. The premenopausal and postmenopausal women were recruited and classified using a comprehensive questionnaire.

Results: There were statistically significant increases in TC, LDL-C, TG and AIP but there was no significant difference in HDL-C level between premenopausal and postmenopausal women. Only LDL-C level was significantly increased in premenopausal women above 45 years of age compared with the premenopausal women between 22-45 years of age.

Conclusion: Menopause alters lipid profile. Atherogenic index of plasma which is a marker of plasma atherogenicity may be used to asses risk of developing atherosclerosis in postmenopausal women.

Key words: Menopause, lipid profile, atherogenic index of plasma.

birtakım yapısal, fizyolojik ve biyokimyasal değişikliklere neden olur. Östrojenin antiaterojenik ve koroner arter hastalıklarına karşı koruyucu etkileri bilinmektedir. Geniş bir çalışma olan "Nurses' Health Study" de bilateral ooferektomi geçiren kadınlarda kardiyovasküler hastalık riskinin 8 kat arttığ

${ }^{I}$ Tekden Hastanesi Kardiyoloji Bölümü, Ístanbul, Türkiye

${ }^{2}$ Medical Park Hastanesi Kardiyoloji Bölümü, İstanbul, Türkiye

Yazışma Adresi /Correspondence: Cennet Yıldız,

Özel Tekden Hastanesi Kardiyoloji ABD, İstanbul, Türkiye Email: cennet_yildiz@live.com

Geliş Tarihi / Received: 24.11.2014, Kabul Tarihi / Accepted: 07.03.2015

Copyright @ Dicle Tıp Dergisi 2015, Her hakkı saklıdır / All rights reserved 
gösterilmiştir [1]. Yine "Women Health Initiative" çalışmasında histerektomi geçiren kadınların 10 yıllık miyokardiyal enfarktüs ve koroner hastalıklara bağl1 ölüm riskinin belirgin biçimde arttığ saptanmiştır [2].

Menopoz ile birlikte plazma lipitleri ve lipoproteinlerinde olumsuz değişiklikler meydana gelir. Postmenopozal kadınlarda total kolesterol (TK), düşük yoğunluklu lipoprotein kolesterol (LDL-K), çok düşük yoğunluklu lipoprotein kolesterol (VLDL-K) ve trigliserid (TG) düzeyleri premenopozal kadınlara göre daha yüksektir [3]. Pek çok epidemiyolojik çalışmada yüksek LDL-K ve düşük yüksek yoğunluklu lipoprotein kolesterol (HDL-K) düzeylerinin ateroskleroz patogenezinde önemli rol oynadığ1 gösterilmiştir, Ulusal kolesterol eğitim programı üçüncü erişkin tedavi paneli (NCEP ATP III) kılavuzu başlangıç tedavi hedefini LDL-K kolesterol düzeylerinin düşürülmesi olarak tavsiye etmektedir [4]. Ancak TG konsantrasyonlarının kardiyovasküler risk profili açısından önemi genel olarak gözardı edilmektedir. Yüksek TG seviyesi artmış koroner arter hastalığı riski ve küçük yoğun LDL-K partikülleri ile birliktedir [5,6]. log (TG/HDL-K) oranı plazma aterojenik indeksi (PAI) olarak tanımlanır. PAI, HDL-K ve LDL-K partiküllerinin büyüklüğü ve kolesterolün fraksiyonel esterifikasyonu ilişkilidir. Bu oran, aterojenik küçük LDL-K ve HDL-K partiküllerinin varlığını, koroner ateroskleroz ve kardiyovasküler riski yansitır ve kardiyovasküler risk faktörlerini değerlendirirken ek fayda sağlar [7].

Çalışmamızın amacı premenopozal ve postmenopozal Türk kadınlarında TK, LDL-K, HDL-K, TG düzeylerini, PAI'ni hesaplamak ve yaşın lipit profili üzerine olan etkilerini göstermektir.

\section{YÖNTEMLER}

Prospektif olarak yapılan bu çalışmamıza Mart 2013 ile Mayıs 2014 tarihleri arasında Tekden Hastanesi Kardiyoloji polikliniğine kontrol maksatlı olarak başvuran, herhangi bir kardiyak yakınması olmayan toplam 448 kadın alındı. Bu kadınların 153 tanesi postmenopozal dönemde, 295 tanesi ise premenopozal dönemde idi. .Postmenopozal kadınların yaşları 48 ile 75 yıl arasında bulunmaktaydı; ortalama değeri 57.4 \pm 6.4 idi. Premenopozal grubun ise yaş dağılımı 22 ile 51 y1l arasında olup ortalamaları $37.4 \pm 6.1$ idi. Premenopozal grup ayr1ca yaşları 25-45 yıl ile 45-51 yıl olmak üzere iki gruba ayrildı. Olguların TK, LDL-K, HDL-K, TG düzeyleri PAI değerleri karşılaştırıldı. Medipol Üniversitesi etik kurulu çalışmayı onayladı (etik kurul no: 10840098-234) ve her hastadan çalışma öncesi onay alındi. Hepatik veya renal disfonksiyon, diyabetes mellitüs, hipertansiyon, tiroid fonksiyon bozukluğu, respiratuvar hastalik, pulmoner hipertansiyon, ciddi nörolojik hastalık, malignite hikayesi, adet düzensizliği olan ve hormon replasman tedavisi alan olgular çalışma dışı bırakıldı.

Tüm hastalara yatar pozisyonda 12-derivasyonlu elektrokardiyografi (Comen CM100B, China) ve Amerikan Ekokardiyografi Derneği'nin kılavuzuna uygun olarak ekokardiyografik incleme (Vivid 3 pro, GE Vingmed Ultrasound AS, Horten, Norway) yapıld1 [8]. Sol ventrikül duvar hareket kusuru, kalp kapak hastalığ 1 , sol ventrikül hipertrofisi, iskemik kalp hastalığ 1 , koroner arter bypass grefti (CABG) operasyonu ve/veya peruktan transluminal koroner anjiyoplasti (PTKA) - stent öyküsü olan, EKG'de sol dal bloğu olan hastalar çalışmaya alınmadı.

Kan örnekleri sabah saatlerinde aç karnına olacak şekilde antekubital venden alındı. Örnekler aynı gün biyokimya laboratuvarında çalışıldı. Hastaların tümünün TK, LDL-K, HDL-K, TG (COBAS c311, Roche Diagnostics, Germany) ölçümleri yapıldı.

\section{İstatistiksel Analiz}

Tüm verilerin girişi ve istatistiksel analizi "SPSS for Windows 20.0" (SPSS Inc. Chicago, Illinois, USA) programı kullanılarak yapıldı. Sayısal değişkenler ortalama \pm standart sapma olarak sunuldu. İki grubun ortalama değerlerinin karşılaştırılması için bağımsız iki örnek T testi (Independent-samples T test) kullanıld1. P değerinin $<0.05$ olması istatistiksel olarak anlamlı kabul edildi.

\section{BULGULAR}

İki grubun lipit dağılımı yönünden karşılaştırılması Tablo 1'de özetlenmiştir. Postmenopozal kadınlarda serum TK, TG, LDL-K düzeylerinde istatistiksel olarak anlamlı bir yükselme saptanırken, HDL-K seviyesinde ise anlamlı bir fark saptanmadı. PAI (log TG/HDL-K) menopoz öncesi kadınlarda $-0,14 \pm 0,3$ 
olarak saptand1, postmenopozal kadınlarda ise $0,04 \pm 0,3$ değerine yükseldiği görüldü $(\mathrm{p}<0,001)$.

Tablo 2, 22-45 yaş arası ve $>45$ yaş üstü premenopozal kadınların serum lipit profilini göstermektedir. Her iki grup arasında TK, TG, HDL-K seviyeleri ve PAI açısından fark gözlenmezken, LDL-K seviyesi 45 yaş üstü premenopozal kadınlarda anlamlı olarak yüksek saptandı.

Tablo 1. Premenopozal ve postmenopozal kadınlarda lipit değerleri

\begin{tabular}{lccc}
\hline & $\begin{array}{c}\text { Premenopozal } \\
(\mathrm{n}=295)\end{array}$ & $\begin{array}{c}\text { Postmenopozal } \\
(\mathrm{n}=153)\end{array}$ & p değeri \\
\hline TK $^{\#}$ & $192,0 \pm 40,2$ & $227,0 \pm 40,5$ & $<0,001$ \\
$\mathrm{TG}^{*}$ & $104,9 \pm 72,9$ & $147,6 \pm 75,8$ & $<0,001$ \\
$\mathrm{HDL}^{+} \mathrm{K}^{\dagger}$ & $56,5 \pm 14,7$ & $54,3 \pm 15,4$ & $\mathrm{NS}$ \\
$\mathrm{LDL}^{\S}$ & $112,1 \pm 36,6$ & $140,4 \pm 34,4$ & $<0,001$ \\
PAI $^{* *}$ & $-0,14 \pm 0,3$ & $0,04 \pm 0,3$ & $<0,001$ \\
\hline
\end{tabular}

†HDL-K: Yüksek yoğunluklu lipoprotein kolesterol, §LDL-K: Düşük yoğunluklu lipoprotein kolesterol, "*PAl: Plazma aterojenik indeksi "TG: Trigliserid, "TK: Total kolesterol.

Tablo 2. 22-45 yaş arası ve $>45$ yaş premenopozal kadınların lipit değerleri

\begin{tabular}{lccc}
\hline & $22-45$ yaş & $>45$ yaş & p değeri \\
\hline TK $^{\#}$ & $191,1 \pm 41,1$ & $197,7 \pm 34,0$ & NS \\
TG $^{*}$ & $103,9 \pm 76,3$ & $111,5 \pm 46,2$ & NS \\
HDL-K $^{\dagger}$ & $56,7 \pm 14,8$ & $54,5 \pm 14,4$ & NS \\
LDL-K$^{\S}$ & $110,4 \pm 38,01$ & $122,5 \pm 24,0$ & 0,009 \\
PAI $^{* *}$ & $-0,15 \pm 0,29$ & $-0,07 \pm 0,23$ & NS \\
\hline
\end{tabular}

†HDL-K: Yüksek yoğunluklu lipoprotein kolesterol, §LDL-K: Düşük yoğunluklu lipoprotein kolesterol, "*AAl: Plazma aterojenik indeksi "TG: Trigliserid, \#TK: Total kolesterol.

\section{TARTIŞMA}

Kadınlarda koroner arter hastalığı erkeklere göre yaklaşık 10 yıl geç ortaya çıkar ancak prognozu daha kötü ve mortalite daha yüksektir. Bu gecikmenin nedeni östrojen hormonunun koruyucu etkisine bağlanmaktadır. Östrojen, hücre hipertrofisini azaltır, damar duvarının elastikiyetini artırır ve olas1lıkla aynı oranda ateroskleroza maruz kalmasına rağmen lumenin daha az daralmasına neden olur [9]. Menopozla birlikte obezite, hipertansiyon ve dislipidemi birlikteliği artar [10]. Bu süreçte plazma TK, LDL-K, VLDL-K ve TG düzeyleri artar.
HDL-K düzeyleri ile ilgili veriler ise çelişkilidir. HDL-K düzeylerinin bazı çalışmalarda yükseldiği [11], diğerlerinde ise düştüğü [12-14] veya herhangi bir değişiklik olmadığı saptanmştır [15-18]. Bu dönemde sadece kolesterol düzeylerinde yükselme meydana gelmez, aynı zamanda daha aterojenik bir profil oluşur. Östrojen antioksidan özelliği ile arteriyel endotelyal hasarı azaltmakta, trombosit agregasyonunu ve adezyon oluşmasını engellemektedir. Premenopozal dönemde azalmaya başlayan östrojen, postmenopozal dönemde daha da azalır. Total kolesterol, trigliserid ve LDL-K artar [19]. Menopozla birlikte hemostatik sistemde de, prokoagülan faktör VII, fibrinojen ve plasminojen aktivatör inhibitörü-1 düzeylerinde artışa bağlı olarak koagülasyona eğilim olur. Bu durum menopoz sonras1 kadınlarda ani artış gösteren akut iskemik olayları açıklamaktadır [20].

Yapılan çalışmalarda ateroskleroz patogenezinde yüksek LDL-K ve düşük HDL-K düzeylerinin önemi ortaya konmuştur. Ayrıca son zamanlarda yüksek trigliserid düzeylerinin de koroner kalp hastalığ 1 için bağımsız bir risk faktörü olduğunu gösterilmiştir [21,22]. TG ve HDL-K arasındaki ilişki ile ilgili olarak pekçok çalışma yapılmıştır ve yüksek TG/HDL-K oranı ile koroner arter hastalığı arasında güçlü bir ilişki olduğu ve bu oranın miyokard enfarktüsünün güçlü bir belirleyicisi olduğu saptanmıştır [23,24]. PAI, Dobiasova ve Frohlich tarafindan ortaya atılan ve molar TG ve HDL-K oranının logaritmik transformasyonu olarak tanımlanan bir değerdir [7]. PAI, HDL-K fraksiyonel esterifikasyonu ile pozitif, LDL-K partikül büyüklüğü ile negatif korelasyon gösterir ve kardiyovasküler risk faktörlerini değerlendirirken ek fayda sağlar. $-0,3$ ile 0,1 arası PAI değerlerinin düşük, 0,1-0,24 arası değerlerin orta, 0,24 üzeri değerlerin yüksek kardiyovasküler risk ile birlikte olduğu ileri sürülmüştür [25]. Sögüt ve ark. yapmış olduğu çalışmada PAI'nin anjiyografik olarak tespit edilen koroner kalp hastal1ğının en kuvvetli biyokimyasal göstergesi ve öngördürücüsü olduğunu gösterilmiştir [26].

Bizim çalışmamızda TK, LDL-K, TG düzeyleri ve PAI postmenopozal kadınlarda anlamlı olarak yüksek bulundu. HDL-K düzeyinde ise premenopozal ve postmenopozal kadinlara arasında anlam$l_{1}$ fark saptanmadı. Menopoz ile lipit dağılımında meydana gelen değişikliklerin sebebi muhtemelen 
östrojenlerin serum lipitleri üzerinde yaptığı etkinin ortaya kalkmasıdır.

Usoro ve ark. Yapmış oldukları çalışmada 45 yaş üstü kadınlarda 25-45 yaş ile karşılaştırdıklarında TK, LDL-K seviyelerini ve PAI değerini anlamlı olarak yüksek HDL-K seviyesini ise anlamlı olarak düşük bulmuşlardır [27]. Yapılan başka bir çalışmada ise ilerleyen yaş ile birlikte TK, LDL-K, TG ve VLDL-K seviyelerinin arttığ1 gösterilmiştir [28]. Biz çalışmamızda yaşın lipit profili üzerindeki olası etkilerini değerlendirmek amacı ile premenopozal kadınları 45 yaş üstü ve 22-45 yaş olmak üzere iki gruba ayırdık. Menopoz etkilerinin görülmemesi amacı ile postmenopozal kadınları bu olguların içine almadık. İki grup karşılaştırıldığında TK, HDL-K TG seviyelerinde ve PAI değerinde anlamlı bir fark saptanmazken, LDL-K seviyeleri 45 yaş üstü kadınlarda anlamlı olarak yüksek bulundu.

Ülkemizde bu konu ile ilgili yapılmış en büyük çalışma Onat ve ark. yaptığı TEKHARF (Türk Erişkinlerinde Kalp Hastalığı ve Risk Faktörleri) çalışmasıdır. $\mathrm{Bu}$ çalışmanın 13 yıllık bulgularına baktığımızda; Türk kadınlarının düşük HDL-K (Ort. $45 \mathrm{mg} / \mathrm{dl}$ ) düzeylerine sahip olduğu gözlenmiştir. Kadınlarda ilerleyen yaş ile birlikte trigliserid seviyelerinde artış saptanmıştır [29]. METSAR çalışmasında ise HDL-K düzeyi kadınlarda $52 \mathrm{mg} /$ dl bulunmuştur [30]. Açık ve ark. çalışmalarında, kolesterol düzeyinin kadınlarda yaşla birlikte yükseldiğini belirtmektedir [31]. Bizim çalışmamızda hem premenopozal hem de postmenopozal kadınlarda HDL-K düzeyleri önceki çalışmalardan daha yüksek bulunurken, menopoz sonrası TK ve TG düzeyleri anlamlı olarak yüksek bulunmuştur ki bu bulgu TEKHARF çalışması ve Açık ve ark. yapmış olduğu çalışma ile uyumludur [29].

Sonuç olarak, postmenopozal kadınlarımızın daha kötü bir lipit profiline sahip olduğu söylenebilir. Bu kadınlarda hormon replasman tedavisi ve lipit düşürücü tedavinin yerinin tartışmalı olduğu düşünüldüğünde [32] uygun diyet, sosyal ve fiziksel alışkanlıkların verilmesi daha da önem taşımaktadır.

\section{KAYNAKLAR}

1. Colditz GA, Willett WC, Stampfer MJ, et al. Menopause and the risk of coronary heart disease in women. N Engl J Med 1987;316:1105-1110.
2. Hsia J, Barad D, Margolis K, et al. Usefulness of prior hysterectomy as an independent predictor of Framingham risk score (The Women's Health Initiative). Am J Cardiol 2003;92:264 -269.

3. Matthan MR, Jalbert SM, Lamon-Fava S, et al. TRL, IDL, and LDL Apolipoprotein B-100 and HDL Apolipoprotein A-I kinetics as a function of age and menopausal status. Arterioscler Thromb Vasc Biol 2005;25:1691-1696.

4. National Cholesterol Education Program (NCEP) Expert Panel on Detection, Evaluation, and Treatment of High Blood Cholesterol in Adults (Adult Treatment Panel III). Third Report of the National Cholesterol Education Program (NCEP) Expert Panel on Detection, Evaluation, and Treatment of High Blood Cholesterol in Adults (Adult Treatment Panel III) final report. Circulation 2002;106:3143-3421.

5. Hokanson JE, Austin MA. Plasma triglyceride level is a risk factor to cardio vascular disease independent of high density lipoprotein cholesterol level: a meta-analysis of population based prospective studies. J Cardiovasc Risk 1996; 3:213-219.

6. Guerin M, Legoff W, Lassel TS, et al. Proatherogenic role of elevated CE transfer from HDL to VLDL and dense LDL in type 2 diabetics. Arterioscler Thromb Vasc Biol 2001; 21:282-287.

7. Dobiásová M, Frohlich J. The plasma parameter log (TG/ HDL-C) as an atherogenic index: Correlation with lipoprotein particle size and esterification rate in apoB-lipoproteindepleted plasma (FER (HDL)). Clin Biochem 2001;34:583588 .

8. Schiller NB, Shah PM, Crawford M, et al. Recommendations for quantitation of the left ventricle by two-dimensional echocardiography. American Society of Echocardiography Committee on Standards, Subcommittee on Quantitation of Two- Dimensional Echocardiograms. J Am Soc Echocardiogr 1989;2:358-367.

9. Xing D, Nozell S, Chen Y, et al. Estrogen and Mechanisms of Vascular Protection. Arterioscler Thromb Vasc Biol 2009;29:289-295.

10. Ramos RG, Olden K. The prevalence of metabolic syndrome among US women of childbearing age, Am J Public Health 2008;98:1122-1127.

11. Wu ZY, Wu XK, Zhang YW. Relationship of menopausal status and sex hormones to serum lipids and blood pressure. Int J Epidemiol 1990;19: 297-302.

12. Poehlman ET, Toth MJ, Ades PA, Rosen CJ. Menopauseassociated changes in plasma lipids, insulin-like growth factor I and blood pressure: a longitudinal study. Eur J Clin Invest 1997;27:322-326.

13. Stevenson JC, Crook D, Godsland IF. Influence of age and menopause on serum lipids and lipoproteins in healthy women. Atherosclerosis 1993; 98:83-90.

14. Matthews KA, Meilahn E, Kuller LH, et al. Menopause and risk factors for coronary heart disease. N Engl J Med. 1989;321:641- 646 .

15. Davis CE, Pajak A, Rywik S, et al. Natural menopause and cardiovascular disease risk factors. The Poland and US Col- 
laborative Study on Cardiovascular Disease Epidemiology. Ann Epidemiol 1994;4:445-448.

16. Brown SA, Hutchinson R, Morrisett J, et al. Plasma lipid, lipoprotein cholesterol, and apoprotein distributions in selected US communities. The Atherosclerosis Risk in Communities (ARIC) Study. Arterioscler Thromb 1993;13:1139 -1158 .

17. Demirovic J, Sprafka JM, Folsom AR, et al. Menopause and serum cholesterol: differences between blacks and whites. The Minnesota Heart Survey. Am J Epidemiol 1992;136:155-164.

18. Bonithon-Kopp C, Scarabin PY, Darne B, et al. Menopauserelated changes in lipoproteins and some other cardiovascular risk factors. Int J Epidemiol 1990;19:42-48.

19. The writing group for the PEPI trial. Effects of estrogen or estrogen/progestin regimens on heart disease risk factors in postmenopausal women. JAMA 1995;273:199-208.

20. Rosano GM, Fini M. Postmenopausal women and cardiovascular risk: impact of hormone replacement therapy. Cardiol Rev 2002;10:51-60.

21. Sarwar N, Danesh J, Eiriksdottir G, et al. Triglycerides and the risk of coronary heart disease: 10,158 incident cases among 262,525 participants in 29 Western prospective studies. Circulation 2007;115:450-458.

22. Patel A, Barzi F, Jamrozik K, et al. Serum triglycerides as a risk factor for cardiovascular diseases in the Asia-Pacific region. Circulation 2004;110:2678-2686.

23. da Luz PL, Favarato D, Faria-Neto JR Jr, et al. Highratio of triglycerides to HDL-cholesterol predicts extensive coronary disease. Clinics (Sao Paulo) 2008;63:427-432.
24. Gaziano JM, Henne kens CH, O.Donnell CJ, et al. Fasting triglycerides, high density lipoprotein, and risk of myocardial infarction. Circulation 1997;96:2520-2525.

25. Nwagha UI, Ikekpeazu EJ, Ejezie FE, et al. Atherogenic index of plasma as useful predictor of cardiovascular risk among postmenopausal women in Enugu, Nigeria. Afr Health Sci 2010;10:248-252.

26. Söğüt E, Avcı E, Üstüner F, Arıkan E. Serum aterojenite indeksi olarak (TG/HDL-K) oranının değerlendirilmesi. Türk Klinik Biyokimya Derg 2006; 4:1-8.

27. Usoro CAO, Adikwuru CC, Usoro IN, Nsonwu AC. Lipid profile of postmenopausal women in Calabar, Nigeria. Pak J Nutr 2006;5:79-82.

28. Haarbo J, Hassager C, Schlemmer A, Christianson C, Influence of smoking, body fat distribution and alcohol consumption on serum lipids, lipoproteins and apolipoproteins in early postmenopausal women, Atherosclerosis, 1990;84: 239-244.

29. Onat A. Lipids, Lipoproteins and apolipoproteins among Turks, and impact on coronary heart disease - Invited Review. Anadolu Kardiyol Derg 2004;4:236-245.

30. Kozan Ö, Oğuz A, Abacı A, et al. Prevalence of the metabolic syndrome among Turkish adults. Eur J Clin Nutr 2007;61:548-553.

31. Açık Y, Sezer E, Sezer H. Frequency and distribution of risk factors for coronary heart disease in the adult population of rural district of Elazıg Turkey. Turk J Med Sci 1999;29:265-272.

32. Igweh JC, Nwagha IU, Okaro JM. The effects of menopause on the serum lipid profile of normal females of South East Nigeria. Nigerian J Physiol Sci 2005;20:48-53. 